\title{
TRANSFORMACE BENTONITU PŘI INTERAKCI S VODOU
}

\author{
Bentonite transformation during its interaction with water \\ Veronika Kubcová, Josef Zeman, Dana Hanuláková \\ Ústav geologických věd PřF MU, Kotlářská 2, 61137 Brno; e-mail: 327653@mail.muni.cz
}

Key words: bentonite, water, substrate, transformation, geochemical modeling

\begin{abstract}
Bentonite is a clayey rock, which is planed to be used as an engineer barrier at building a deep storage of nuclear waste. The bentonite sample from the deposit Rokle and two reacting media, both natural and synthetical waters, were used for the experimental study of the mineral stability in aqueous environment at temperature of $95{ }^{\circ} \mathrm{C}$. From experimental data, changes of chemical composition of the system were quantified. Based on the program Geochemist's Workbench ${ }^{\circledR}$, the model of bentonite-water interaction was derived. Major changes in the composition of water takes place during the first three months and the composition of water has very little effect on stability and properties of bentonite.
\end{abstract}

\section{Úvod}

Jaderný odpad je radioaktivní materiál, který nemá další vhodné využití. Proto je potřeba se zabývat jeho finálním uložením a zabezpečením. Izolování odpadu $\mathrm{v}$ hlubinném úložišti je založeno na multibariérovém principu. Celý systém se skládá ze dvou základních částí. První část je př́rodní bariéra, což je geologické prostředí. Druhou částí je inženýrská bariéra, což je vícevrstvá bariéra obsahující bentonit kolem kontejneru s odpadem. Bentonit je reziduální, nepřemístěná jílovitá hornina, tvořená smektity s vysokou sorpční schopností, vysokou hodnotou kationtové výměnné kapacity, značnou expandabilitou a plastičností (Acros et al. 2006). Na složení se podílejí i akcesorické minerály jako jsou křemen, živce, sulfidy (pyrit), sádrovec a karbonáty, kde je nejvíce zastoupen kalcit (Acros et al. 2003). Tyto minerály mohou mít zásadní vliv na přeměnu bentonitu a mohou následně ovlivnit transport radionuklidů $\mathrm{v}$ prrípadě poškození kontejneru (Karnland et al. 2006). Bentonit by měl zabránit pronikání vody do úložišš̌ a zároveň sorbovat radioaktivní izotopy

Tab. 1: Základní chemická analýza bentonitu Rokle.

Tab. 1: Basic chemical analysis of bentonite Rokle.

\begin{tabular}{|c|c|c|c|c|c|}
\hline \multicolumn{7}{|c|}{ Před interakcí } \\
\hline složka & $\begin{array}{c}\text { původní } \\
\text { hmot. \% }\end{array}$ & $\begin{array}{c}\text { bez vody } \\
\text { hmot. \% }\end{array}$ & složka & $\begin{array}{c}\text { původní } \\
\text { hmot. \% }\end{array}$ & $\begin{array}{c}\text { bez vody } \\
\text { hmot. \% }\end{array}$ \\
\hline$-\mathrm{H}_{2} \mathrm{O}$ & 9,83 & & $\mathrm{MgO}$ & 2,13 & 2,36 \\
\hline$+\mathrm{H}_{2} \mathrm{O}$ & 6,71 & 7,43 & $\mathrm{~K}_{2} \mathrm{O}$ & 0,94 & 1,04 \\
\hline $\mathrm{SiO}_{2}$ & 43,72 & 48,44 & $\mathrm{Na}_{2} \mathrm{O}$ & 0,26 & 0,29 \\
\hline $\mathrm{TiO}_{2}$ & 4,17 & 4,62 & $\mathrm{Li}_{2} \mathrm{O}$ & 0 & 0 \\
\hline $\mathrm{Al}_{2} \mathrm{O}_{3}$ & 13,85 & 15,35 & $\mathrm{~S}$ & 0,01 & 0,01 \\
\hline $\mathrm{Fe}_{2} \mathrm{O}_{3}$ & 14,47 & 16,03 & $\mathrm{CO}$ & 0,25 & 0,28 \\
\hline $\mathrm{FeO}$ & 0,11 & 0,12 & $\mathrm{P}_{2} \mathrm{O}_{5}$ & 0,83 & 0,92 \\
\hline $\mathrm{MnO}$ & 0,14 & 0,16 & $\mathrm{C}$ & 0 & 0 \\
\hline $\mathrm{CaO}$ & 2,66 & 2,95 & $\mathrm{Celkem}$ & 100,08 & 100 \\
\hline
\end{tabular}

$\mathrm{m}$ - čas interakce v měsících $\mathrm{v}$ př́padě porušení kontejneru a jejich úniku do okolního prostředí. Z tohoto hlediska je rozhodující dlouhodobá stabilita bentonitu a stálost jeho minerálního prostředí. Cílem práce bylo (1) vyhodnocení změn chemického složení vody a bentonitu při jejich vzájemné interakci a (2) určení hlavních procesů přeměny bentonitu při této interakci.

\section{Metodika}

Jako substrát byl vybrán čistý bentonit z lokality Rokle (bentonit Rokle). Tento bentonit (tab. 1) má relativně vysoký podíl hliníku a trojmocného železa. Jako roztoky byly použity dva typy vody (tab. 2): (1) prrírodní podzemní voda ze štoly Josef (Podzemní laboratoř Josef, kterou provozuje Centrum experimentální geotechniky, Fakulta stavební, ČVUT, označena jako voda Josef) a (2) syntetická voda se zvýšeným obsahem draslíku (označena jako voda VŠCHT). Voda Josef má výrazně vyšší celkovou mineralizaci a vyšší koncentrace všech složek s výjimkou draselných a chloridových iontů. Těmito složkami jsou u syntetické vody VŠCHT vytvořeny vyšší hnací síly na přeměnu montmorillonitu.

Čtyři kg bentonitu byly pečlivě promíseny se 3 litry př́slušné vody a vzniklá suspenze byla uzavřena v ocelové nádobě a zahřátá na teplotu $95^{\circ} \mathrm{C}$. Experiment probíhal po dobu osmnácti měsíců, postupně byly odebírány vzorky nasyceného bentonitu po 3, 6, 12 a 18 měsících pro analýzu.

Z experimentálních dat byly vytvořeny časové závislosti fyzikálně-chemických parametrů a koncentrací vybraných složek vod a bentonitu. Pro geochemické modelování bylo využito modulů React a Act programu Geochemist's Worbench $^{\circledR} 7.0$ (Bethke a Yeakel 2008).

\section{Výsledky a jejich diskuze}

Hodnota $\mathrm{pH}$ se v průběhu experimentu u vody Josef výrazně neměnila. Hodnoty $\mathrm{pH}$ ve vodě Josef se pohybova- 
Tab. 2: Složení sytících médií Josef a VŠChT v průběhu jejich interakce s bentonitovým substrátem Rokle.

Tab. 2: Composition of water media Josef a VŠChT during their interaction with bentonite substrate Rokle.

\begin{tabular}{|c|c|c|c|c|c|c|c|c|c|c|c|}
\hline & \multicolumn{5}{|c|}{ Voda Josef } & \multicolumn{5}{|c|}{ Voda VŠCHT } \\
\hline & & počátek & $3 \mathrm{~m}$ & $6 \mathrm{~m}$ & $12 \mathrm{~m}$ & $18 \mathrm{~m}$ & počátek & $3 \mathrm{~m}$ & $6 \mathrm{~m}$ & $12 \mathrm{~m}$ & $18 \mathrm{~m}$ \\
\hline $\mathrm{Mg}^{2+}$ & $\mathrm{mg} \cdot \mathrm{l}^{-1}$ & 32,9 & 18,7 & 18,3 & 9,2 & 18,5 & 5,1 & 18,4 & 18,1 & 9,3 & 23,4 \\
\hline $\mathrm{Ca}^{2+}$ & $\mathrm{mg} \cdot \mathrm{l}^{-1}$ & 85,3 & 82,7 & 86 & 44,9 & 89,4 & 14,8 & 89,4 & 90,4 & 43,5 & 104 \\
\hline $\mathrm{K}^{+}$ & $\mathrm{mg} \cdot \mathrm{l}^{-1}$ & 3,0 & 12,3 & 15,1 & 6,7 & 12,8 & 108,3 & 19,1 & 11,8 & 9,7 & 18 \\
\hline $\mathrm{Na}^{+}$ & $\mathrm{mg} \cdot \mathrm{l}^{-1}$ & 14,7 & 40,9 & 37,0 & 23,3 & 43,1 & 5,5 & 33,3 & 36,5 & 18,6 & 40,7 \\
\hline $\mathrm{SiO}_{2}$ & $\mathrm{mg} \cdot \mathrm{l}^{-1}$ & 0 & 65,8 & 68,2 & 23,6 & 38,7 & 0,0 & 59,0 & 67,5 & 33,6 & 39,3 \\
\hline $\mathrm{Cl}^{-}$ & $\mathrm{mg} \cdot \mathrm{l}^{-1}$ & 10,5 & 24,7 & 26,6 & 16,2 & 34,0 & 42,5 & 49,6 & 56,2 & 36,5 & 67,4 \\
\hline $\mathrm{SO}_{4}^{2-}$ & $\mathrm{mg} \cdot \mathrm{l}^{-1}$ & 165 & 192,2 & 193,5 & 82,3 & 227,6 & 133,3 & 186,5 & 176,2 & 90,1 & 181,7 \\
\hline $\mathrm{HCO}_{3}^{-}$ & $\mathrm{mg} \cdot \mathrm{l}^{-1}$ & 233 & 163,7 & 145,3 & 118,4 & 150,9 & 11,8 & 163,7 & 162,1 & 118,4 & 109,1 \\
\hline $\mathrm{pH}$ titr & & & 8,2 & 7,6 & 7,8 & 8,2 & & 8,0 & 7,7 & 7,8 & 8,0 \\
\hline $\mathrm{pH}$ & & & 7,5 & 7,7 & 7,6 & 7,5 & & 7,7 & 7,9 & 7,5 & 7,2 \\
\hline $\mathrm{Eh}^{*}$ & $\mathrm{mV}$ & & 208,0 & 124,0 & 87,0 & 159,5 & & 185,5 & 129 & 174,8 & 169,7 \\
\hline Eh & $\mathrm{mV}$ & & 415,0 & 331,0 & 294,0 & 366,5 & & 392,5 & 336 & 381,8 & 376,7 \\
\hline kondukt. & $\mathrm{uScm}^{-1}$ & & 706,0 & 738,0 & 415,0 & 803,0 & & 787,0 & 793,0 & 421,0 & 933,0 \\
\hline $\mathrm{T}$ & C & & 26,7 & 21,2 & 25,0 & 23,0 & & 27,1 & 21,2 & 24,8 & 23,0 \\
\hline TDS & $\mathrm{mg} \cdot \mathrm{l}^{-1}$ & 544,4 & 600,9 & 589,0 & 324,6 & 615,1 & 321,3 & 619,1 & 618,9 & 315,8 & 584,6 \\
\hline$\sum$ kationů & $\mathrm{mekvl}^{-1}$ & 7,7 & 7,8 & 7,8 & 4,2 & 8,2 & 4,2 & 7,91 & 7,9 & 4,0 & 9,4 \\
\hline$\sum$ anionů & mekv l$^{-1}$ & 7,6 & 7,4 & 7,2 & 4,1 & 8,2 & 4,2 & 8,0 & 7,9 & 4,1 & 7,5 \\
\hline
\end{tabular}

$\mathrm{m}$ - čas interakce v měsících

Tab. 3: Chemické složení bentonitového substrátu Rokle v průběhu jeho interakce se sytícími médii Josef a VŠChT.

Tab. 3: Chemical composition of bentonite substrate Rokle during its interaction with water media Josef and VŠChT.

\begin{tabular}{|l|l|c|c|c|c|c|c|c|c|}
\hline \multicolumn{2}{|c|}{} & \multicolumn{3}{|c|}{ Po interakci sodou Josef } & \multicolumn{3}{c|}{ Po interakci sodou VŠChT } \\
\hline prvky & $\begin{array}{c}\text { hmot. } \\
\%\end{array}$ & $\begin{array}{c}\text { hmot. } \\
\%\end{array}$ & $\begin{array}{c}\text { hmot. } \\
\%\end{array}$ & $\begin{array}{c}\text { hmot. } \\
\%\end{array}$ & $\begin{array}{c}\text { hmot. } \\
\%\end{array}$ & $\begin{array}{c}\text { hmot. } \\
\%\end{array}$ & $\begin{array}{c}\text { hmot. } \\
\%\end{array}$ & $\begin{array}{c}\text { hmot. } \\
\%\end{array}$ & $\begin{array}{c}\text { hmot. } \\
\%\end{array}$ \\
\hline $\mathrm{H}$ & 0,83 & 0,81 & 0,87 & 0,89 & 0,86 & 0,8 & 0,86 & 0,87 & 0,87 \\
\hline $\mathrm{Si}$ & 22,64 & 22,39 & 22,34 & 22,5 & 22,58 & 22,33 & 22,52 & 22,62 & 22,54 \\
\hline $\mathrm{Ti}$ & 2,77 & 2,81 & 2,79 & 2,77 & 2,83 & 2,77 & 2,76 & 2,77 & 2,80 \\
\hline $\mathrm{Al}$ & 8,12 & 7,95 & 7,82 & 7,83 & 7,88 & 8,02 & 7,86 & 7,86 & 7,88 \\
\hline $\mathrm{Fe}^{\mathrm{III}}$ & 11,21 & 12,03 & 11,89 & 11,7 & 11,55 & 11,9 & 11,67 & 11,67 & 11,8 \\
\hline $\mathrm{Fe}$ & 0,09 & 0,08 & 0,02 & 0,04 & 0,09 & 0,10 & 0,05 & 0,04 & 0,08 \\
\hline $\mathrm{Mn}$ & 0,12 & 0,15 & 0,13 & 0,12 & 0,12 & 0,14 & 0,12 & 0,12 & 0,13 \\
\hline $\mathrm{Ca}$ & 2,11 & 1,99 & 2,39 & 2,25 & 2,78 & 2,26 & 2,31 & 2,2 & 2,05 \\
\hline $\mathrm{Mg}$ & 1,42 & 1,45 & 1,31 & 1,35 & 1,02 & 1,41 & 1,31 & 1,34 & 1,36 \\
\hline $\mathrm{K}$ & 0,86 & 0,88 & 0,84 & 0,77 & 0,63 & 0,89 & 0,87 & 0,76 & 0,80 \\
\hline $\mathrm{Na}$ & 0,21 & 0,22 & 0,21 & 0,20 & 0,17 & 0,22 & 0,23 & 0,21 & 0,18 \\
\hline $\mathrm{Li}$ & 0,00 & 0,00 & 0,00 & 0,00 & 0,00 & 0,00 & 0,00 & 0,00 & 0,00 \\
\hline $\mathrm{S}$ & 0,01 & 0,01 & 0,00 & 0,01 & 0,03 & 0,01 & 0,00 & 0,02 & 0,01 \\
\hline $\mathrm{C}^{\mathrm{IV}}$ & 0,08 & 0,03 & 0,03 & 0,01 & 0,00 & 0,04 & 0,03 & 0,01 & 0,01 \\
\hline $\mathrm{P}$ & 0,4 & 0,42 & 0,41 & 0,41 & 0,42 & 0,42 & 0,41 & 0,4 & 0,42 \\
\hline $\mathrm{C}^{0}$ & 0,00 & 0,00 & 0,00 & 0,00 & 0,00 & 0,00 & 0,00 & 0,00 & 0,00 \\
\hline $\mathrm{O}$ & 49,11 & 48,78 & 48,96 & 49,16 & 49,02 & 48,70 & 49,00 & 49,12 & 49,07 \\
\hline & 100,00 & 100,00 & 100,00 & 100,00 & 100,00 & 100,00 & 100,00 & 100,00 & 100,00 \\
\hline
\end{tabular}

$\mathrm{m}$ - čas interakce $\mathrm{v}$ měsících

ly v rozmezí 7,51-7,68 a ve vodě VŠCHT v rozmezí 7,207,93 . Hodnoty oxidačně-redukčního potenciálu Eh ve vodě Josef i ve vodě VŠCHT nejdříve výrazně klesly a následně stouply. Ve vodě Josef se hodnoty Eh pohybovaly v rozmezí 294-415 mV a ve vodě VŠCHT v rozmezí 336-392 mV. Složení vod Josef a VŠChT popsáno v tabulce 2.

Zásadní změny v koncentraci rozpuštěných látek se odehrály v prvních třech měsících interakce. Celko- vé množství rozpuštěných minerálů bentonitu v prvním půlroce vzrostlo zhruba až na dvojnásobek, na hodnotu kolem $600 \mathrm{mg} / \mathrm{l}$. Vodivost stoupla zhruba o $100 \mu \mathrm{S} / \mathrm{cm}$. Přechodný pokles koncentrací (tab. 3) může být spojen s rekrystalizací novotvořených malých krystalů, které jsou rozpustnější než krystaly větších rozměrů (Ostwaldovo zrání). Hlavní změny složení vod se při interakci s bentonitem odehrály $\mathrm{v}$ průběhu prvních tří měsíců, do půl roku se složení stabilizovalo a v dalším roce docházelo k malému poklesu koncentrací.

Rozhodující změny montmorillonitu a dalších jílových minerálů bentonitu jsou charakterizovány změnou koncentrace a výměnou alkalických kovů a kovů alkalických zemin $\mathrm{Na}, \mathrm{K}$, $\mathrm{Mg}$ a $\mathrm{Ca}$. Změny se zřetelně projevují na poměru hlavních kationtů $\mathrm{Mg} / \mathrm{Ca}$, $\mathrm{Ca} / \mathrm{Na}$ a $\mathrm{K} / \mathrm{Na}$ (obr. 1 ) ve vodě a bentonitu. U bentonitu dochází k výraznému snížení poměru $\mathrm{Mg} / \mathrm{Ca}$ v obou vodách. $\mathrm{U}$ poměru $\mathrm{Ca} / \mathrm{Na}$ dochází $\mathrm{v}$ obou typech vod $\mathrm{k}$ poklesu a $\mathrm{v}$ substrátu ke zvýšení. Znamená to, že vápník se váže do bentonitu $\mathrm{z}$ vody a sodík se uvolňuje. U poměru K/Na v bentonitu $s$ vodou Josef zůstávají poměry v průběhu interakce stabilní. U poměru K/Na bentonitu s vodou VŠCHT dochází ke zvýšení v bentonitu a výraznému snížení ve vodě, draslík se ve srovnání se sodíkem přednostně váže v bentonitu. Složení výsledných vod není primárně určováno množstvím daného prvku v substrátu.

Geochemický model interakce vod Josef a VŠCHT se substrátem je uveden na obrázku 2. Modelové trendy principiálně odpovídají trendům, které byly zjištěny experimentálně. Na základě provedených laboratorních experimentů dochází $\mathrm{k}$ přeměně kolem půl hmotnostního procenta bentonitu. Modelování probíhalo tak, že $\mathrm{k} 1 \mathrm{~kg}$ modelové vody byl přidáván substrát a sledovány postupné změny jednotlivých parametrů. Interakce substrátu končí po tom, kdy se voda stane nasycená vůči přidávaným minerálům a při dalším přidávání už pouze roste jejich množství v systému. V průběhu interakce dochází $\mathrm{k}$ tomu, že sodné a vápenaté koncové členy montmorillonitové řady jsou nahrazovány jejich hořečnatými a draselnými analogy. Výsledky jsou v každém kroku kontrolovány z hlediska jejich reálnosti a tam, kde jsou k dispozici analytické údaje, jsou s nimi porovnávány. Při interakcích mezi vodou a substrátem se nechá interakce 

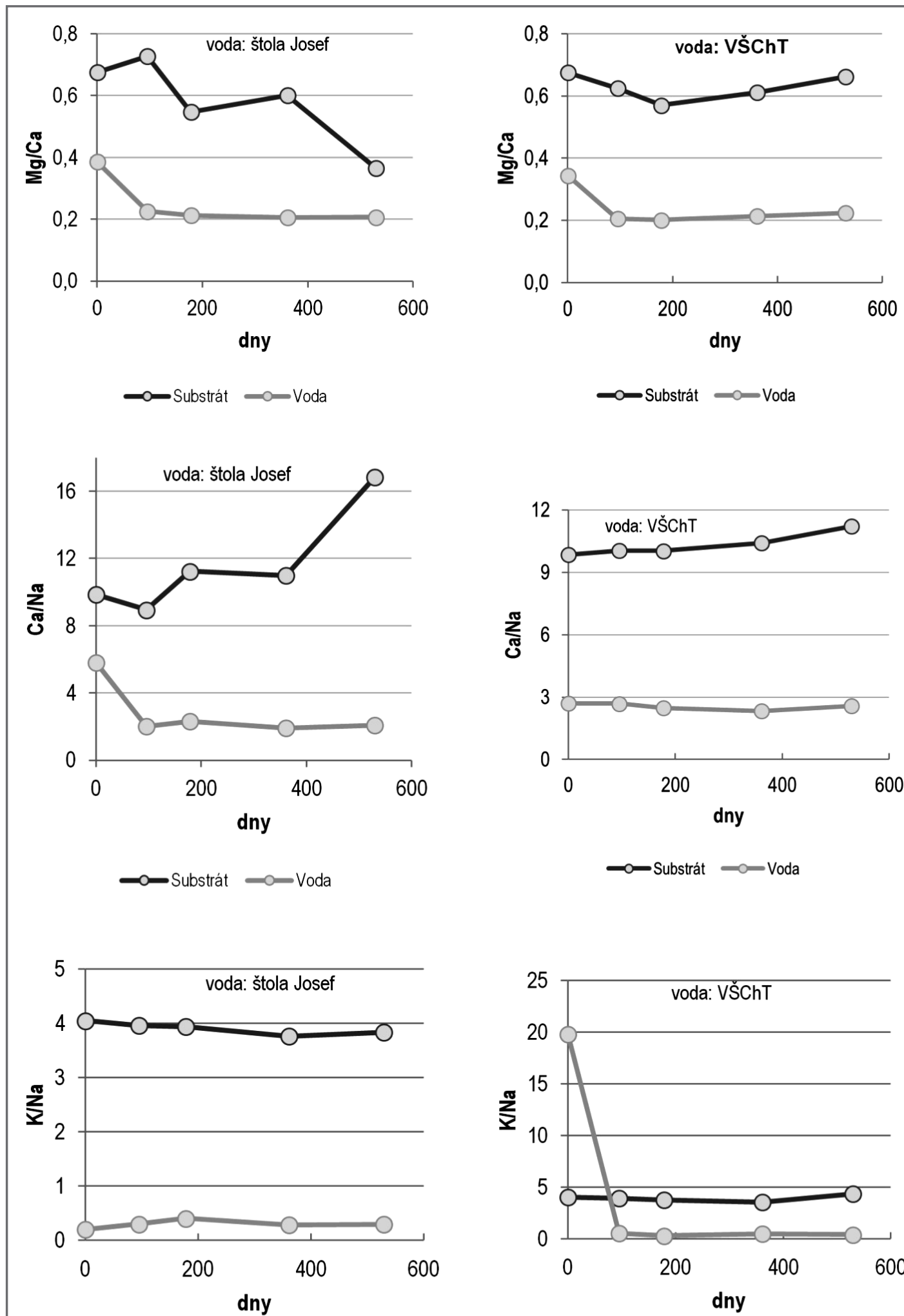

Obr. 1: Změny poměrů $\mathrm{Mg} / \mathrm{Ca}, \mathrm{Ca} / \mathrm{Na}$ a $\mathrm{K} / \mathrm{Na}$ v bentonitu a vodách během vzájemné interakce.

Fig. 1: Evolution of $\mathrm{Mg} / \mathrm{Ca}, \mathrm{Ca} / \mathrm{Na}$ and $\mathrm{K} / \mathrm{Na}$ ratios in the bentonite - water systems during interaction.

probíhat do stupně pokročilosti reakcí tak, až je dosaženo stabilních podmínek, které se dále nemění ( $\mathrm{pH}$, Eh a množství rozpuštěných látek zůstává konstantní).

\section{Závěr}

Bentonit byl smíchán s vodou a suspenze se zahřívala až na $95^{\circ} \mathrm{C}$. Interakce mezi bentonitem a vodami je při teplotě $95{ }^{\circ} \mathrm{C}$ poměrně rychlá, po třech měsících 


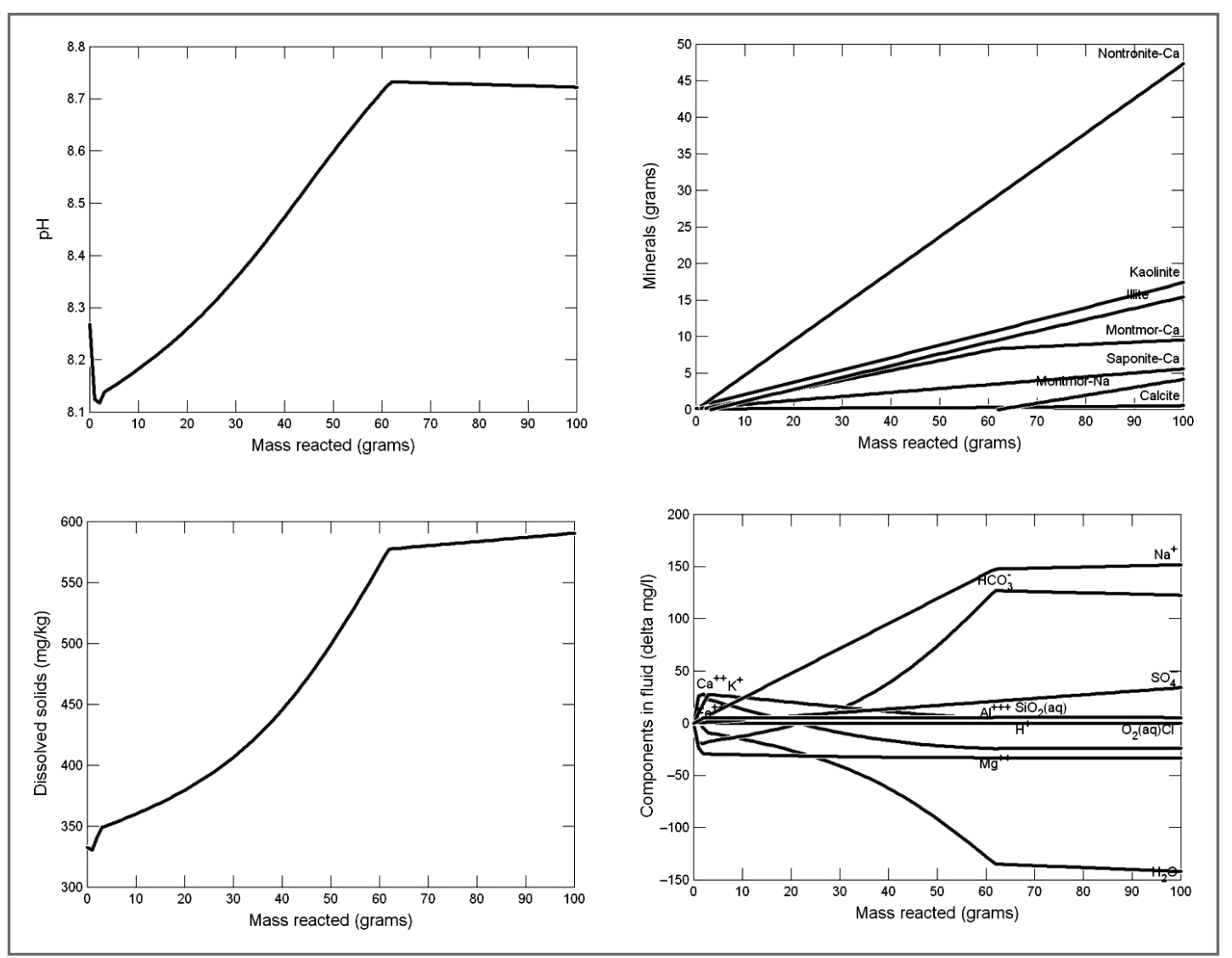

Obr. 2: Modelový vývoj pH, minerálního složení pevné fáze, celkové množství rozpuštěných látek (TDS) a koncentrací jednotlivých složek ve vodě v průběhu interakce bentonitu Rokle s vodou Josef.

Fig. 2: Modeled evolution of $\mathrm{pH}$, mineral composition, TDS and concentrations of aqueous components during interaction of the bentonite sample with the water Josef.

bylo dosaženo relativně stabilního složení bentonitu a vody (voda odpovídající prírodní vodě ze štoly Josef a syntetická voda). Změny v obsazích jednotlivých složek horniny jsou malé. Hlavní změny ve složení vod se při interakcích s bentonity $\mathrm{z}$ hlediska kationtů odehrají v průběhu prvních tř́ měsíců, do půl roku se složení stabilizuje a v dalším roce už dochází jen k malému poklesu koncentrací spojeného se zráním nově vytvořených minerálů. Složení interagujících vodných médií má jen velmi malý vliv na stabilitu a vlastnosti bentonitu. Pokud je koncentrace některé složky nižší, než odpovídá rovnováze s bentonitem, pak je do vodného prostředí doplněna a naopak. Dochází k vázání vápníku a hořčíku z vod do substrátu, k uvolňování sodíku a draslík je u vody s jeho vysokou koncentrací vázán do substrátu, u vody s jeho nízkou koncentrací je naopak do vody ze substrátu uvolňován. Eh a $\mathrm{pH}$ nemají patrný vliv na stabilitu substrátu. Také teplota v rozmezí $23-95^{\circ} \mathrm{C}$ má jen malý vliv.

Modelové trendy principiálně odpovídají trendům, které byly zjištěny experimentálně a jsou použitelné pro modelování systému i za odlišných podmínek. Studie potvrdila vhodnost bentonitu pro sledované účely.

\section{Poděkování}

Provedená studie byla finančně podpořena $z$ Institucionální podpory výzkumu Masarykovy univerzity v roce 2009 a v rámci projektu Správy úložišt radioaktivních odpadů

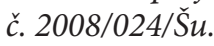

\section{Literatura}

Acros, D. - Bruno, J. - Karnland, O. (2003): Geochemical model of the granite-bentonite-groundwater interaction at Äspö HRL (LOT experiment). - Applied Clay Science, 23, 219-228.

Acros, D. - Grandia, F. - Domenech, C. (2006): Geochemical evolution of the near field of a KBS-3 repository. - SKB TR 06-16, 1-97. Stockholm.

Bethke, C. M. - Yeakel, S. (2008): GWB Essentials Guide. - The Geochemists Workbench Release 8.0. Hydrogeology Program, 1-100, University of Illinois. Urbana.

Karnland, O. - Olsson, S. - Nilsson, U. (2006): Mineralogy and sealing properties of various bentonites and smectite-rich clay materials. - SKB TR-06-30, 1-117. Stockholm. 